\title{
Designing and building earthquake warning system with Arduino and web-based SES60 SLP sensor
}

\author{
Edidas ${ }^{1}$, Rusnardi Rahmat Putra ${ }^{2,3}$ \\ ${ }^{1}$ Department of Electronic Engineering, Universitas Negeri Padang, Padang, Indonesia \\ ${ }^{2}$ Department of Civil Engineering, Universitas Negeri Padang, Padang, Indonesia \\ ${ }^{3}$ Head Research Center for Disaster, Universitas Negeri Padang, Padang, Indonesia
}

\begin{tabular}{l} 
Article Info \\
\hline Article history: \\
Received May 24, 2021 \\
Revised Sep 8, 2021 \\
Accepted Jan 14, 2022 \\
\hline
\end{tabular}

Keywords:

Earthquake vibration

Earthquake warning

Ground motion

Vibration device

\begin{abstract}
Indonesia is a country that is crossed by a world ring of fire that has the potential for earthquakes and tsunamis. An earthquake is an occurrence of shaking the ground due to the sudden release of energy into the earth. Since earthquakes occur within an undetermined period, we need a device to detect earthquake vibrations as early as possible within few seconds and announce real-time warning information on the website. The monitor screen displays a flat, a slightly increasing, the alarm displays a sound "weak earthquake", "moderate earthquake", "strong earthquake", "very strong earthquake". When there are no earthquake waves, very small shaking, PGA>200 gals, PGA>400 gals, PGA $>600$ gals and PGA $>800$ gals respectively. The alarm announces watch out (hati-hati) for moderate earthquake PGA>200 gals, caution (waspada) PGA $>400$ gals and ask to evacuate for PGA>600 gals. The earthquakes detecting devices are useful in reducing their negative impacts, for instance, fatalities and material losses. The development of this system is to provide faster and more accurate information, and we can access the information on the internet network with broad coverage. The system can send the information within 5 second to user.
\end{abstract}

This is an open access article under the $\underline{C C B Y-S A}$ license.

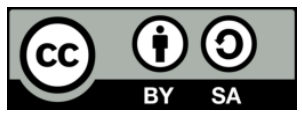

\section{Corresponding Author:}

Rusnardi Rahmat Putra

Department of Civil Engineering, Head of Research Center for Disaster

Universitas Negeri Padang, Jalan Dr. Hamka Air Tawar Padang, Indonesia

Email: rusnardi.rahmat@ft.unp.ac.id

\section{INTRODUCTION}

Padang is a city located in the Western Indonesian archipelago, the city closes to three earthquake resources. Based on the seismicity data, 4000 earthquakes occurred from 1779 to 2020 with magnitude $\mathrm{Mw}>4$ as shown in Figure 1(a) and some of them created tsunami in Indonesia shows in Figure 1(b) [1]-[3], and similar to Palu city [4], [5]. Earthquakes are disasters that often occur in areas located in plate regions. The earthquakes happen in a large force or a small force. Small force earthquakes often cannot be felt by people because they do not cause strong vibrations. Thus, many people do not realize if this earthquake occurs. Unlike small force earthquakes, large force earthquakes have powerful vibration. They can cause a lot of trouble, this earthquake disaster is a problem that can make people worry and can produce victims in the future.

Earthquakes are occurrences shaking the ground due to the release of energy in the earth that is suddenly marked by a broken layer of rock in the earth's crust [6], [7]. The accumulation of energy that causes earthquakes is from the movement of tectonic plates [7]. The energy formed is emitted in all directions as earthquake waves. Thus, we can feel the effect on the surface of the earth. Most people commonly do not feel earthquakes with a magnitude below 3 on the richter scale [8], [9]. However, when the earthquake occurred around the scale of $7-8$, the power was strong enough to destroy buildings and other public places. The 
earthquakes centered in sea areas or subductions have the potential to cause tsunamis [9], [10]. Earthquakes occur within an undetermined period because of that we need a device to detect earthquake vibrations as early as possible within 24 hours. The detecting devices are useful in reducing the negative impacts, for instance, fatalities, and material losses.

Padang is the capital of West Sumatra Province, close to three earthquake sources such as the Megathrust Zone, the Mentawai Fault, and the Great Sumatra Fault on the mainland. Due to the fact that the impact of the earthquake can create a tsunami event in the future. The proposed device was installed at at the ground surface in Universitas Negeri Padang.

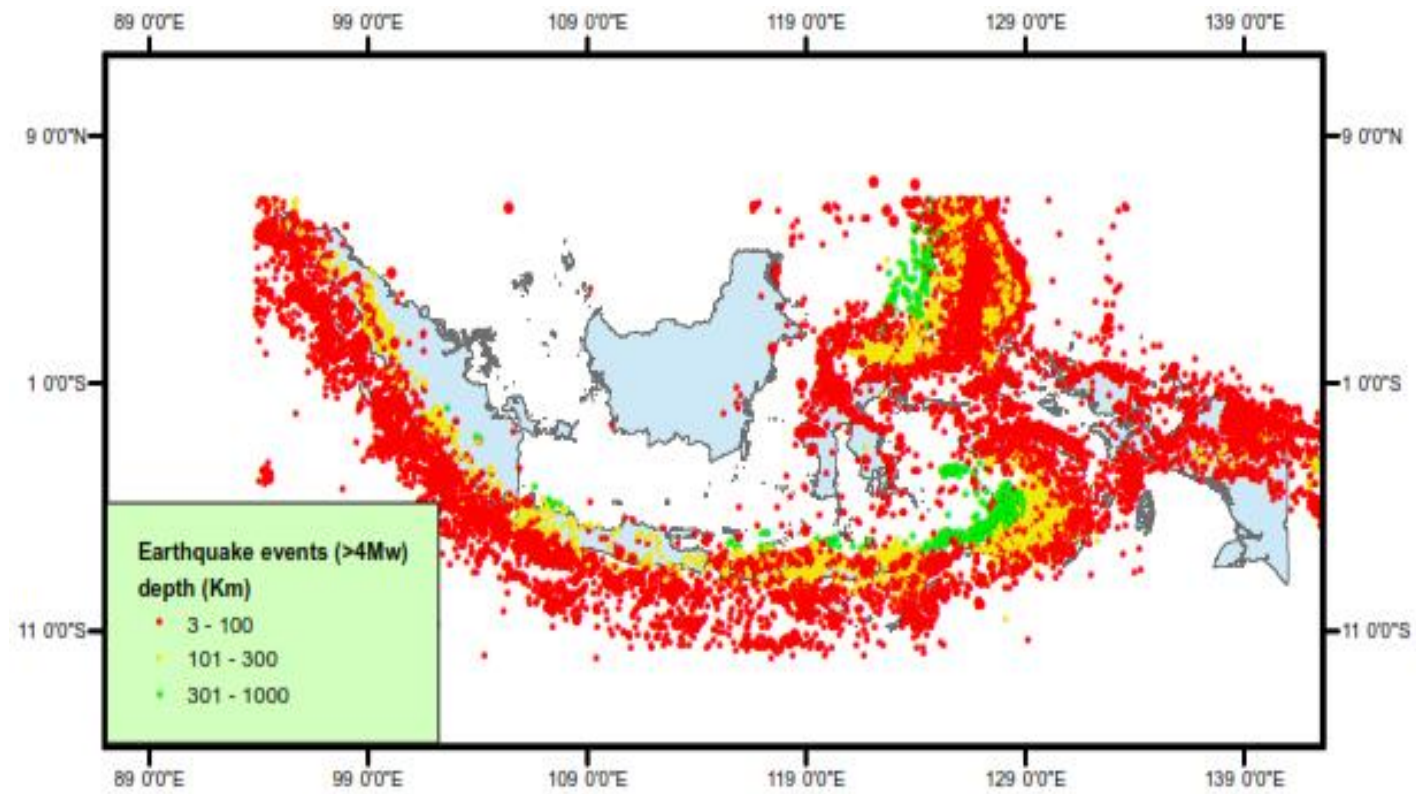

(a)

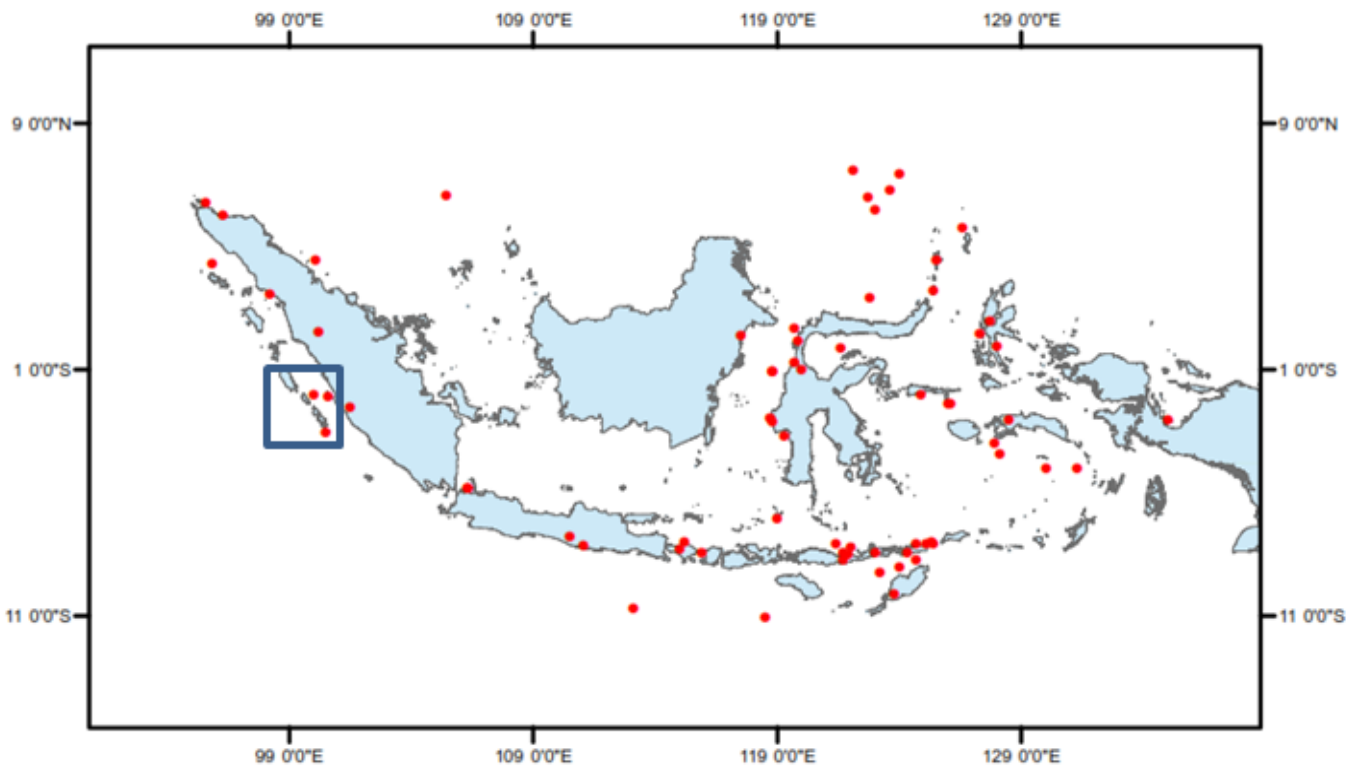

(b)

Figure 1. Seismicity and historical of tsunami (a) seismicity of Indonesia from 1779-2020 with magnitude $>4$ and (b) the tsunami history of Indonesia from 1600-2020, the blue box is the location of the tsunami that affected Padang city 
The progress of science and technology in this globalization era is quite rapid. There are many electronic devices used by people that can put them at ease. Physics, electronics, and instrumentation studies have the potential to also contribute to the development of this science and technology. This development can be identified from the transition from mechanical or manual systems to digital systems. A digital system is a combination of devices designed to manipulate physical quantities or information depicted in digital form. Digital electronics are broadly used such as electronic measuring devices, counting systems, computers, microprocessors, and microcontrollers [10], [11]. Since digital systems have high accuracy, they produce considerably accurate data. Previous research on the development of earthquake response and warning system using the SES60 earthquake sensor is still has some shortcomings including the alarms as a voice warning equipment, and data can only be known when logging into the web and can only be accessed by one computer at the same time. Developing this system to provide information more quickly and accurately, to ease the broad coverage accessed through the internet network is needed [12].

The designing and making earthquake alarms with attractive designs and high accuracy is needed. We propose a designing and building earthquake warning system with Arduino and web-based SES60 SLP sensor. Selected SLP sensor because this sensor is realtime information and the filtering is manageable. This system automatically send the message on the monitor screen displays a flat, a slightly increasing, the alarm displays a sound "weak earthquake", "moderate earthquake", "strong earthquake", "very strong earthquake". When there are no earthquake waves, very small shaking, PGA>200 gals, PGA>400 gals, PGA>600 gals and PGA $>800$ gals respectively. The alarm announces watch out (hati-hati) for moderate earthquake PGA $>200$ gals, caution (waspada) PGA>400 gals and ask to evacuate for PGA>600 gals.

Earthquake early warning system, there are five earthquake early warning systems. Each of them is designed based on the topography of the location. The first one is in Mexico, which borders the pacific ocean directly, some earthquakes detecting sensors in offshore subduction zones that can trigger alarms in Mexico City [12]. The second one is in Romania, the system is designed to provide earthquake early warning in the Carpathian Mountains to the city of Bucharest, 100 miles from the source of the earthquake [13]-[17]. The third one is in Japan, after the huge earthquake in 1995 that took 6000 lives, Japan built 2000 earthquake stations to provide early warnings to all the country's area. Two other systems exist in Turkey and Taiwan, and five more are being tested in China, Switzerland, Italy, Hawaii, and California [18], [19]. Earthquakes are vibrations that start from the earth due to fractures or extreme shifting that generate powerful trembles on the earth's surface. An earthquake is not preventable, the occurrence is sudden, and the time can not be detected [20].

Basic concept of SES60 SLP sensor, SES60 SLP sensor was produced by Yamatake Company. The intelligent earthquake sensor is a detector that can estimate the damage caused by seismic motion. The using the output of the built-in accelerometer, the SES60 SLP sensor calculates SI values, which correspond to the measured seismic intensity, and maximum synthetic acceleration, that is used to estimate the damage caused by an earthquake. Besides, the sensor can assess the occurrence of liquefaction events on earth after earthquake vibrations occur. The SES60 SLP sensor and its connection as shown in Figures 2 and 3. The sensor also can show the direction of acceleration from the epicenter. The SES60 SLP sensor specifications are in Table 1. Figure 3 shows installed SLP device SES 60 sensor.

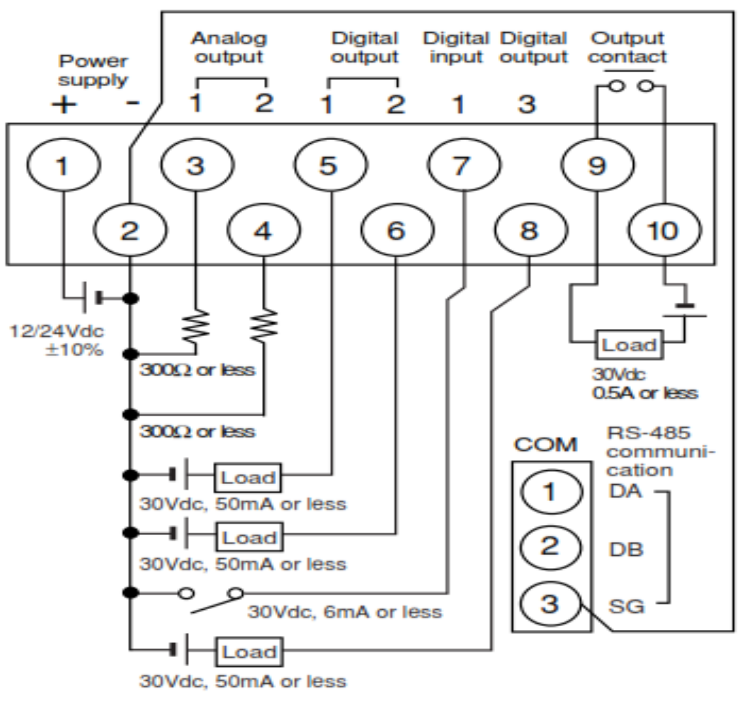

Figure 2. Wiring connector for SLP device

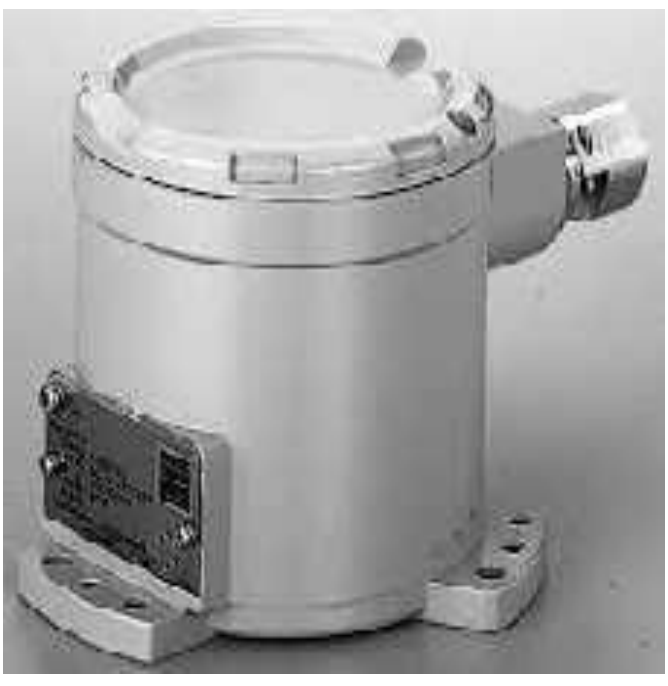

Figure 3. LSP SES60 sensor 
Table 1. SES60 SLP sensor specifications

\begin{tabular}{ll}
\hline \multicolumn{1}{c}{ Item } & \multicolumn{1}{c}{ Specification } \\
\hline Range & \pm 2000 gal $(\mathrm{X}, \mathrm{Y}, \mathrm{Z}$ axis) \\
Measures & 1 gal by DC acceleration meter, DC-50 Hz (X, Y axis), DC-30 Hz (Z axis) \\
Acceleration & $10 \mathrm{~ms}$ \\
Power & $12 \mathrm{Vdc} \pm 10 \%$ or $24 \mathrm{Vdc} \pm 10 \%$ \\
Power consumption & $4 \mathrm{~W}$ max. (Including 4-20 mA output) \\
Seismic sensing & Relay 1a (contact output) \\
Output & Open collector NPN \\
4 to $20 \mathrm{~mA}$ & Can be chosen from SI value, acceleration \\
Diagnostic input & Current photocoupler input sources \\
RS-communication & Type 3 wire, 19200 bps \\
Waveform & $120 \mathrm{~s} \times 10$ (10 ms sampling) \\
Temperature & about -10 to $+60^{\circ} \mathrm{C}$ (No freezing point) \\
Explosion proof & Exd II BT4X (explosion resistant structure) \\
Water resistance & IP67 (1 m under water for 30 minutes) type JIS C 0920 waterproof (excluding metal cable conduit) \\
Mass & $1.8 \mathrm{~kg}$ \\
\hline
\end{tabular}

Arduino Uno is an ATmega328 based microcontroller board. The Arduino Uno has 14 input pins of digital output; 6 input pins as PWM output; 6 analogue input pins; $16 \mathrm{MHz}$ crystal oscillator; USB connection; a power jack; ICSP header; and reset button. To support microcontrollers, we can run it by simply connecting the Arduino Uno board to the computer using a USB cable, electricity with an AC-to-DC adapter, or a battery. The name "Uno" means one in Italian, to mark the launch of Arduino 1.0. Uno and 1.0 version will be the reference version of Arduino Uno is the latest version in a series of Arduino USB boards, and as a reference model for the Arduino platform, for comparison with previous versions, see the Arduino board index. Arduino Uno is different from all previous boards in terms of USB-to-serial connections because it uses the Atmega8U2 feature programmed as a USB-to-serial converter while the previous board uses an FTDI driver USB-to-serial chip.

Arduino Uno power can be activated via a USB connection or with an external (automatic) power supply. External (non-USB) power supplies can be either the AC-to-DC adapter or the battery. This adapter can be connected by plugging a center-positive plug jack of a $2.1 \mathrm{~mm}$ size POWER connector. The head of the battery can be inserted into the Gnd and V in header pins of the POWER connector. The recommended power requirements for the Uno board are 7 Volts up to 12 volts. If the power is less than 7 volts, the Uno pin $5 \mathrm{v}$ can still operate but is unstable [21], [22]. When more power is given from $12 \mathrm{~V}$, the voltage regulator can overheat and damage the Uno board.

The digital pin of Arduino Unload is 14 pins that can be used as input or output, using the pinMode (), digitalWrite (), and digitalRead () functions, operating at 5 volts. Each pin can give or receive a maximum of 40 $\mathrm{mA}$ and has an internal pull-up resistor (interrupted by default) of 20-50 KOhms. Arduino Uno has several facilities for communicating with computers, other Arduino, and other microcontrollers. Arduino Uno ATmega328 provides UART TTL (5 V) for serial communication contained in digital pins 0 (RX) and 1 (TX). ATmega328 also acts as a serial communication channel via USB and as a port virtual com for software on computers. ATmega328 also supports I2C (TWI) and SPI communication [23]. Parameters which support this system are such as ADC, power amplifier where speaker output is the output of the signal amplified, and the gain section is for regulating the incoming signal following the sensitivity of the power amplifier[24], alarm where sirens usually have a certain type of sound [25], JavaScript can embed the encoding in an HTML document or a single application [26], [27], and MySQL software is the ability to handle large amounts of data [28], [29].

WEB is a computer network that can provide various information services. It has a collection of several computers connected to a fast telecommunications network. The communication relationship between the website as a source of information with the client as a computer user is called a client-server [30], [31]. On the web, documents with hypertext format contain a variety of information, both in the form of text, images, sound, video, and other multimedia. There are two types of webs. They are static and dynamic web. The static web is a web using HTML [31]. This website cannot continuously maintain the program by following every development that occurs. While in the dynamic web, changing the information on a page can be done without changing the program, and only by changing the data. The application of the web is by connecting the web to a database, and the changes are done by the operator, not the webmaster.

\section{METHOD}

\subsection{Design device's diagrams and manufacture}

The planning of the diagram of designing and manufacturing the earthquake warnings with Arduino and web-based SLP SES60 earthquake sensor is in Figure 4. The diagrams design has the following functions: SES60 earthquake sensor serves to detect an earthquake that occurs. Data output from the sensor will be received by Arduino Uno as a microcontroller to process the sensor data. SES60 sensor data is input 
continuously into Arduino Uno. Arduino Uno as an input and output controller of all circuit work, ethernet Shield is a module used for connecting Arduino Uno to the internet with wire. WEB is a system site page for processing and storing sensor data., the display is useful for displaying sensor data on a PC monitor screen., a power amplifier is useful for magnifying the audio signal to amplify the sound, horn speakers' serine is used to giving a warning if there is an earthquake with a large force [32]-[34]. Serine is made using amplifiers and horn speakers. A power supply is useful for providing power supply for Arduino Uno.

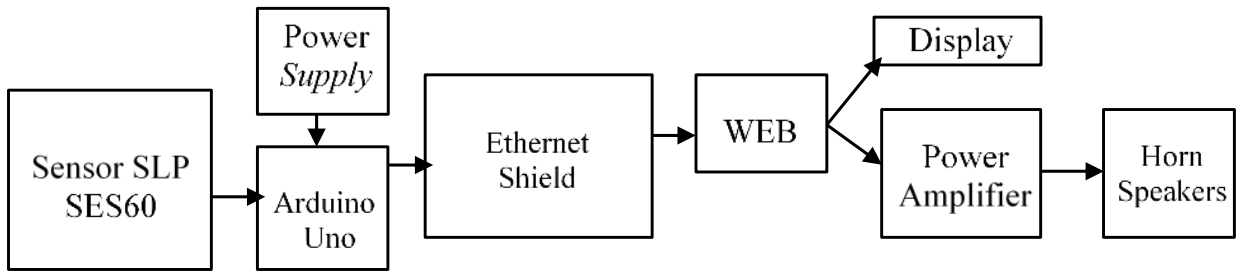

Figure 4. Research flows scheme

\subsection{The device working principle}

In designing this device, the system works automatically. The SES60 sensor will detect the vibrations of the earthquake. The results of the detection are converted to voltage levels. The voltage level is the input in Arduino. Then, the Arduino changes the level data into digital data, then selects them to find out whether there is vibration or not. If Arduino detects an earthquake vibration, the data is sent using the Ethernet Shield module to the webserver. Data on the web server is recorded in the database. The main display of the PC monitor is shown in three parts: the display of the current vibration; the display of the last earthquake; and the history of earthquakes that have occurred. On the web, there is a voice to inform the public about the strength of the earthquake, and mitigation that must be done by the community. This alarm uses an amplifier and horn speaker.

\subsection{Hardware design}

\subsubsection{Mechanical design}

This function of the design is to determine the location of the tools being designed. The form of the mechanical design of the system is in Figure 3. The mechanical design in Figure 5 consists of; i) a PC for a web server, ii) UPS for backup power, iii) power amplifier for audio signal amplifiers, iv) circuit boxes, v) earthquake sensors and (6) horn speakers for audio output.

\subsubsection{Electronic design}

The electronic circuit in this final project is a series of several electronic components into a single unit. The design of this electronic circuit is to support the achievement of the objectives of making this tool. In this designing process, there are 2 schemes involved, including the earthquake sensor scheme and the ethernet shield scheme.

\subsection{Internet, SLP sensor connection and operating tool design diagram}

The SES60 sensor outputs waves propagate through the analog signal terminal. The analog signal that comes out of the SES60 sensor is sent to the Arduino to be processed into digital data. The digital data generated by Arduino is sent to ethernet shield so that it can be sent to the server via the network. Digital data sent from the ethernet shield will be saved to a database on the server. The digital data on the server is then processed by the server into information in the form of graphs and tables then displayed on a web and mobile app. The data in the table is also MP3 data which will be displayed as a warning notification according to the level of the earthquake that occurred and its operating tool design diagram shown in Figures 5 and 6.

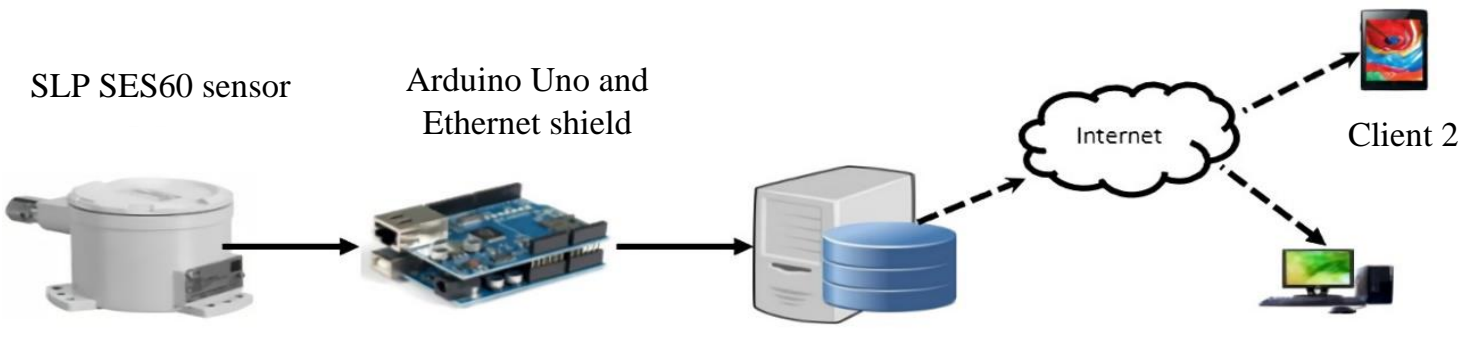

Server

Client 1

Figure 5. Earthquake early warning scheme 


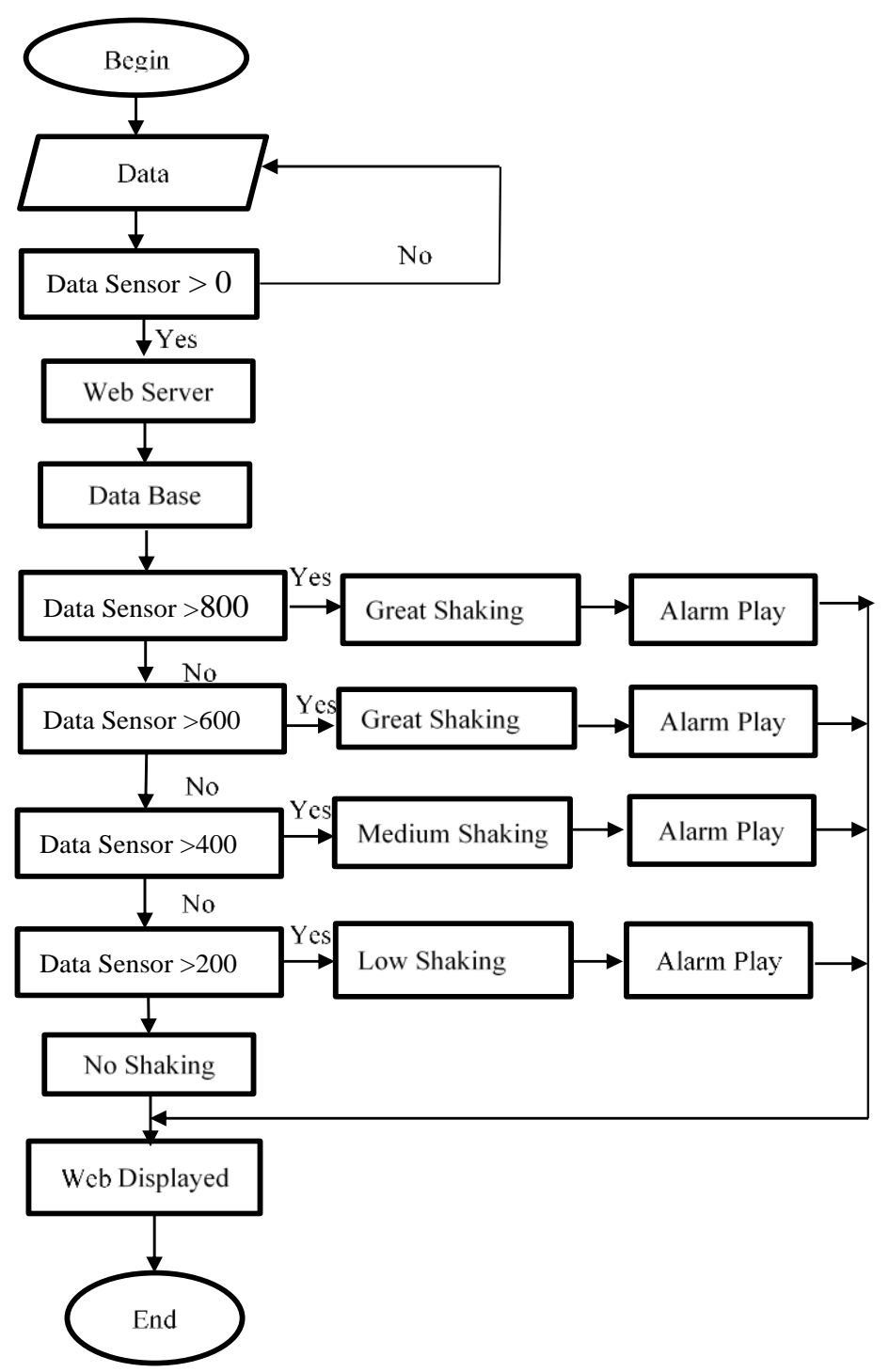

Figure 6. The flowchart of operating tool design

\section{RESULTS AND DISCUSSION}

The output is in acceleration from SLP device, this system can be applied too for others devices such accelerometer and seismograph. The monitor screen displays a flat, a slightly increasing, the alarm displays a sound "weak earthquake", "moderate earthquake", "strong earthquake", "very strong earthquake". When there are no earthquake waves, very small shaking, PGA>200 gals, PGA>400 gals, PGA>600 gals and PGA>800 gals respectively. The alarm announces watch out (hati-hati) for moderate earthquake PGA>200gal, caution (waspada) PGA $>400$ gals and ask to evacuate for PGA $>600$ gals as shown Figure 6.

In this research, the take account as main consideration is on site acceleration, since on site acceleration is real ground motion detected by SLP sensor otherwise the Richter scale energy release. The system has been validated and evaluated by 3 experts on this field, some corrections have been done to improve this system work well such as signal filtering, the displayed output on monitor, how the system takes time, how the alarm work.

The current research results show clear information on the earthquake ground motion level and automatically give a response by bar chart and sounding. This system is not being able to determine how great the shaking in magnitude scales such as in Richter scale, moment magnitude scale, and all the responses based on the received acceleration in gal or in gravity. The system gives a response within 2 seconds after receiving the ground motion wave, it is earlier information than the currently available system in Indonesia. This system information is a local area where the sensor was installed but this system can apply elsewhere [26]. For future 
work, all the received wave from the installed sensor in Indonesia can be integrated into one system, the system gives information more wide [35]-[39].

\section{CONCLUSION}

Prototype designing and building earthquake warning system with Arduino and web-based ses60 SLP sensor can work properly which is able to display the wave level on the monitor screen according to the strength of the earthquake ground motion. The sensor display data on the web on the level of the earthquake ground motion produce alarm notation in the form of an $\mathrm{mp} 3$ file. The $\mathrm{mp} 3$ data from the web is streamed to the speaker/alarm as well. The monitor screen displays a flat, a slightly increasing, the alarm displays a sound "weak earthquake", "moderate earthquake", "strong earthquake", "very strong earthquake". When there are no earthquake waves, very small shaking, PGA>200 gals, PGA>400 gals, PGA>600 gals and PGA>800 gals respectively. The alarm announces watch out (hati-hati) for moderate earthquake PGA $>200$ gals, caution (waspada) PGA $>400$ gals and ask to evacuate for PGA $>600$ gals. The system can send the information within 5 second to user.

\section{ACKNOWLEDGEMENTS}

The author would like to thank the Local Government of Padang City for providing financial support during the assessment in Padang. Especial thanks to my students Rifky who gave the best contribution during the assessment and finally thanks to Universitas Negeri Padang for financial support through research funding with schema Penelitian Kerjasama Luar Negeri dan Penelitian Dasar contract number: /UN35.13/LT/2018, 1012/UN35.13/LT/2021, and 904/UN35.13/LT/2021.

\section{REFERENCES}

[1] M. Irsyam et al., "Development of the 2017 national seismic hazard maps of Indonesia," Earthquake Spectra, vol. 36, no. 1_suppl, 2020, doi: 10.1177/8755293020951206.

[2] R. R. Putra, "Damage investigation and re-analysis of damaged building affected by the ground motion of the 2009 padang earthquake," International Journal of GEOMATE, vol. 18, no. 66, pp. 163-170, Feb. 2020

[3] Sutrisno, R. R. Putra, and Ganefri, "A comparative study on structure in building using different partition receiving expense Earthquake," International GEOMATE Journal, vol. 13, no. 37, pp. 34-39, 2017.

[4] I. G. Tunas, A. Tanga, and S. R. Oktavia, "Impact of landslides induced by the 2018 palu earthquake on flash flood in bangga river Basin, Sulawesi, Indonesia," Journal of Ecological Engineering (JEE), vol. 21, no. 2, 2020, doi: 10.12911/22998993/116325.

[5] P. Supendi et al., "Relocated aftershocks and background seismicity in eastern Indonesia shed light on the 2018 Lombok and Palu earthquake sequences," Geophysical Journal Internationa, vol. 221, no. 3, 2020, doi: 10.1093/gji/ggaa118.

[6] G. Hui, S. Li, P. Wang, Y. Suo, and I. D. Somerville, "Implications of earthquakes for the slab subduction dynamic process in Southeast Asia,” Journal of Asian Earth Sciences, vol. 194, no. 103955, 2020, doi: 10.1016/j.jseaes.2019.103955.

[7] T. Uchide, "Focal mechanisms of small earthquakes beneath the Japanese islands based on first-motion polarities picked using deep learning," Geophysical Journal International, vol. 223, no. 3, December 2020, pp. 1658-1671, doi: 10.1093/gji/ggaa401.

[8] T. Igarashi, "Catalog of small repeating earthquakes for the Japanese Islands," Earth, Planets and Space, vol. 72, no. 73, 2020, doi:10.1186/s40623-020-01205-2

[9] S. Yamamoto, "Earthquake Countermeasure Technology for Small to Huge Earthquakes," Quarterly Report of RTRI, vol. 61, no 3, pp. 161-164, 2020, doi: 10.2219/rtriqr.61.3_161.

[10] N. D. Hananto et al., "Tsunami earthquakes: Vertical pop-up expulsion at the forefront of subduction megathrust," Earth and Planetary Science Letters, vol. 538, no. 116197, 2020, doi: 10.1016/j.eps1.2020.116197.

[11] R. M. Allen and D. Melgar, "Earthquake early warning: Advances, scientific challenges, and societal needs," Annual Review of Earth and Planetary Sciences, vol. 47. 2019, doi: 10.1146/annurev-earth-053018-060457.

[12] J. Santos-Reyes, "Influencing factors on the usefulness of an earthquake early warning system during the 2017 mexico city earthquakes," Sustainability, vol. 13, no. 20, 2021, doi: 10.3390/su132011499.

[13] A. Marmureanu, I. A. Moldovan, V. E. Toader, G. Marmureanu, and C. Ionescu, "Seismic warning time for vrancea earthquakes in three large dams sites situated in the eastern part of Romania," Romanian Reports in Physics, vol. 71, no. 1, 2019.

[14] R. R. Putra, Y. Ono, N. Syah, and A. A. Cantika, "Seismic Performance Evaluation of Existing Building in Earthquake Prone Area Based on Seismic Index and Seismic Demand Method," Civil Engineering and Architecture, vol. 9, no. 4, pp. 1237-1245, 2021, doi: 10.13189/cea.2021.090425.

[15] K. Y. Volkova, V. V. Zverevich, "Digital vs Electronic," Scientific and Technical Libraries, vol. 2020, no. 12, pp. 159-172, 2020, doi: 10.33186/1027-3689-2020-12-159-172.

[16] M. Zaim, R. R. Putra, and N. Rosita, "Language as a Tool for Disaster Mitigation Management: Analysis of Warning System Text in Language and Institutional Framework," Journal of Disaster Research, vol. 16, no. 5, 2021, pp. 817-826, 2021, doi: 10.20965/jdr.2021.p0817.

[17] J. Santos-Reyes, "How useful are earthquake early warnings? The case of the 2017 earthquakes in Mexico city," International Journal of Disaster Risk Reduction, vol. 40, 2019, no.101148, doi: 10.1016/j.ijdrr.2019.101148.

[18] M. Böse, C. Ionescu, and F. Wenzel, "Earthquake early warning for Bucharest, Romania: Novel and revised scaling relations," Geophysical Research Letters, vol. 34, pp. 1-6, 2007, doi: 10.1029/2007GL029396.

[19] Y. Kodera, J. Saitou, N. Hayashimoto, S. Adachi, M. Morimoto, Y. Nishimae, and M. Hoshiba, "Earthquake early warning for the 2016 Kumamoto earthquake: performance evaluation of the current system and the next-generation methods of the Japan Meteorological Agency," Earth, Planets and Space, vol. 68, no. 202, 2016, doi: 10.1186/s40623-016-0567-1.

[20] Yan-Shing Lin, R. W. K. Chan, and Hiroshi Tagawa, "Earthquake early warning-enabled smart base isolation system," Automation 
in Construction, vol. 115, no. 103203, 2020, doi: 10.1016/j.autcon.2020.103203.

[21] I. Stubailo, M. Alvarez, G. Biasi, R. Bhadha, and E. Hauksson, "Latency of waveform data delivery from the southern california seismic network during the 2019 ridgecrest earthquake sequence and its effect on ShakeAlert," Seismological Research Letters, vol. 92, no. 1, pp. 170-186, 2020, doi: 10.1785/0220200211.

[22] S. E. Minson et al., "Real-time performance of the plum earthquake early warning method during the $2019 \mathrm{~m} 6.4$ and 7.1 ridgecrest, california, earthquakes," Bulletin of the Seismological Society of America, vol. 110, no. 4, pp. 1887-1903, 2020, doi: $10.1785 / 0120200021$.

[23] M. Radulian, A. Bălă, E. Popescu, and D. Toma-Dănilă, "Earthquake mechanism and characterization of seismogenic zones in south-eastern part of Romania," Annal of Geophysics, vol. 61, no. 1, 2018, doi: 10.4401/ag-7443.

[24] R. A. S. Rueda, "Use of the flipped classroom to design creative and active activities in the field of computer science," Creativity Studies, vol. 13, no. 1, 2020, doi: 10.3846/cs.2020.10336.

[25] J. Venukumar and N. S., "Arduino Based Door Access Control, "International Journal of Research in Advent Technology, vol. 4, no. 8, pp. 122-124, Aug 2016.

[26] G. Cremen and C. Galasso, "Earthquake early warning: Recent advances and perspectives," Earth-Science Reviews, vol. 205. 2020, doi: 10.1016/j.earscirev.2020.103184.

[27] K. Li, J. Liu ,S. Zhang, Y. Liu, P. Wang, and H. Gao, "Circuit parameter optimization of class e power amplifier for wireless power transmission applications," in EITCE 2020: Proceedings of the 2020 4th International Conference on Electronic Information Technology and Computer Engineering, November 2020, pp. 1162-1166, doi: 10.1145/3443467.3444714.

[28] K. Jakubowski and J. Paś, "Reliability Analysis of Alarm Signals Transmitting Systems Used to Monitoring Buildings," Journal of KONBiN, vol. 50, no. 3, pp. 1-20, 2020, doi: 10.2478/jok-2020-0047.

[29] K. K. Idzham et al., "Study of Artificial Intelligence into Checkers Game using HTML and JavaScript," IOP Conference Series: Materials Science and Engineering, Bangkok, Thailand, vol. 864, 2020, doi: 10.1088/1757-899X/864/1/012091.

[30] Suma S., "Speech/Text Note App Using Javascript And Html," EPRA International Journal of Research and Development (IJRD), vol. 5, no. 5, pp. 129-134, 2020, doi: 10.36713/epra4456.

[31] M. Widenius and D. Axmark, "MySQL Reference Manual,"California: O'reiily Community Press, 2002.

[32] R. A. S. Rueda, "Use of the flipped classroom to design creative and active activities in the field of computer science," Creativity Studies, vol. 13, no. 1, pp. 136-151, 2020, doi: 10.3846/cs.2020.10336.

[33] T. Auer, A. M. MacEachren, C. McCabe, S. Pezanowski, and M. Stryker, "HerbariaViz: A web-based client-server interface for mapping and exploring flora observation data," Ecological Informatics, vol. 6, no. 2, 2011,pp. 93-110, doi: 10.1016/j.ecoinf.2010.09.001.

[34] N. Döring, "Personal home pages on the Web: A review of research," Journal of Computer-Mediated Communication, vol. 7, no. 3, 2002, doi: 10.1111/j.1083-6101.2002.tb00152.x

[35] A. Z. Sabarani and H. Inoue, "Performance estimation of earthquake early warning system for disaster reduction in western Java, Indonesia," Bulletin of the International Institute of Seismology and Earthquake Engineering, vol. 48, 2014

[36] Pei-Yang Lin, "Earthquake early warning systems," International Journal of Automation and Smart Technology (AUSMT), vol. 1, no. 2, pp. 27-34, 2011, doi: 10.5875/ausmt.v1i2.123.

[37] T. Kubo, Y. Hisada, M. Murakami, F. Kosuge, and K. Hamano, "Application of an earthquake early warning system and a realtime strong motion monitoring system in emergency response in a high-rise building," Soil Dynamics and Earthquake Engineering, vol. 31, no. 2, pp. 231-239, 2011, doi: 10.1016/j.soildyn.2010.07.009.

[38] S. Colombelli and A. Zollo, "Rapid and reliable seismic source characterization in earthquake early warning systems: current methodologies, results, and new perspectives," Journal of Seismology, vol. 20, pp. 1171-1186, 2016, doi: 10.1007/s10950-0169570-Z.

[39] Y. O. R. R. Putra, J. Kiyono, and S. K. Vanapalli, "Relationship between Shear Velocities Recorded by Microtremor Observations and Seismic Cone Penetration Test Results," Indonesian Journal of Science and Technology, vol. 6, no. 2, pp. 315-336, 2021.

\section{BIOGRAPHIES OF AUTHORS}

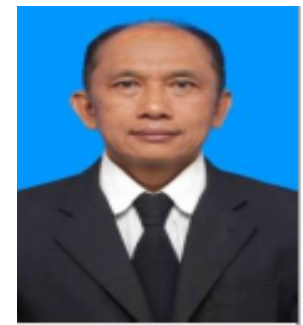

Edidas (iD If SC P was born on February 9, 1963. He received his doctor award from the Electronic Department, Universitas Negeri Yogyakarta. Currently, He is a researcher and lecturer in the electronic department, Universitas Negeri Padang. He did some fundamental research topics such as microcontroller systems, PHP and web. He can be contacted at email: edidasunp@ft.unp.ac.id.

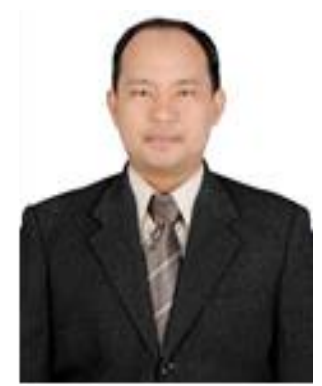

Rusnardi Rahmat Putra (D) 81 SC P received his PhD.Eng from Kyoto University Japan. His major is earthquake engineering. He received a postdoctoral program as an Assistant Professor in 2012-2014 at Earthquake and Life Engineering, Kyoto University, Japan. He succeeded supervised international students for master and doctoral degree level at the same lab, Kyoto University Japan in 2012-2014. He was invited as visiting researcher at the University of Ottawa, Canada in 2015-2016, and Kyoto University in 2019-2020. He published more than 15 scientific articles (reputation journal) indexed by Scopus. He received some international award such as the best paper 2015 and the best presentation 2012 and the best achievement lecturer (dosen terbaik 1 UNP) and the best innovative lecturer (dosen terbaik akademik leader). He is a reviewer for local journal and international journal. Currently, he has written some book in his field. He can be contacted at email: rusnardi.rahmat@ft.unp.ac.id. 